\title{
COMPARED TO WHAT? MENSTRUATION, PREGNANCY, AND THE COMPLEXITIES OF COMPARISON
}

EMILY GOLD WALDMAN*

\section{INTRODUCTION}

When crafting a sex discrimination argument, finding the right comparison can be crucial. Indeed, comparison-drawing has been a key strategy for advocates challenging the constitutionality of the tampon tax. In their 2016 lawsuit challenging New York's tampon tax, the plaintiffs alleged that the New York State Department of Taxation and Finance had imposed a "double standard" when deciding which products would be considered tax-free medical items and which would not. ${ }^{1}$ Their complaint stated:

Medical products exclusively for women are taxed. Medical products also used by men are not. For example, the Department considers Rogaine, foot powder, dandruff shampoo, chapstick, facial wash, adult diapers, and incontinence pads to be medical items. These products are not taxed. But medical items used only by women - tampons and sanitary pads - are taxed. ${ }^{2}$

The comparison argument had powerful rhetorical force-and popular appeal. Within several months after the complaint was filed, New York repealed its tampon tax. ${ }^{3}$ Shortly thereafter, plaintiffs in Florida filed a parallel lawsuit, emphasizing that in deciding which

\footnotetext{
* Professor of Law and Associate Dean for Faculty Development \& Operations, Elisabeth Haub School of Law at Pace University.

${ }^{1}$ Compl. ๆ 2, Seibert v. N.Y. State Dep’t of Tax’n \& Fin., No. 904075-16 (N.Y. Sup. Ct. March 3, 2016).

${ }^{2} I d$. १ๆ $2-4$.

${ }^{3}$ The New York State Legislature voted to repeal the tax on May 25, 2016. See New York Legislature Cuts Taxes on Feminine Hygiene Products, N.Y. TIMES (May 25, 2016), https://www.nytimes.com/2016/05/26/nyregion/new-york-legislature-cuts-taxes-on-feminine-hygieneproducts.html [https://perma.cc/QSH8-6DPQ]. Governor Andrew Cuomo signed the measure on July 21, 2016. See Governor Cuomo Signs Legislation to Exempt Sales and Use Taxes on Feminine Hygiene Products, GOvERNOR ANDREw M. CuOMO (July 21, 2016), https://www.governor.ny.gov/news/governorcuomo-signs-legislation-exempt-sales-and-use-taxes-feminine-hygiene-products [https://perma.cc/GK8AGKGV].
} 
products would meet the statutory definition of "common household remedies," the Florida Department of Revenue had "excluded tampons and pads from the list of nontaxable medical items," while including "adhesive tape, epsom salts, athlete's foot treatment, minoxidil for hair regrowth (i.e., Rogaine), and petroleum jelly" as well as "band-aids, bandages, and gauze." Within a year, Florida had repealed its tampon tax as well. ${ }^{5}$

The website of "Tax Free. Period"- the "legal, advocacy and public engagement campaign founded by Period Equity and LOLA [a menstrual product company] to end the tampon tax in the U.S."-also emphasizes the comparison theme. ${ }^{6}$ Its homepage features an interactive United States map that allows the visitor to click on different states and see which items are tax-exempt in the states that are still taxing tampons and pads. Clicking on Texas, for instance, reveals that "Texas has a tax on tampons, but dandruff shampoo is untaxed." Clicking on many of the other states reveals some arresting comparisons: "Georgia has a tax on tampons, but tattoos are untaxed," "New Mexico has a tax on tampons, but souvenirs at minor league baseball stadiums are untaxed," "Iowa has a tax on tampons, but cotton candy is untaxed," and so on. " "Bingo supplies? Doughnuts? Seriously?" reads the map's caption. ${ }^{8}$

The comparison lens is not unique to the tampon tax. The Pregnancy Discrimination Act (PDA), which amended Title VII to state that the prohibition on discrimination "because of sex" included discrimination "on the basis of pregnancy," frames one of its core protections in comparative terms. It provides that "women affected by pregnancy, childbirth, or related medical conditions shall be treated the same for all employmentrelated purposes ... as other persons not so affected but similar in their ability or

\footnotetext{
${ }^{4}$ Compl. ๆף 39-41, Wendell v. Fla. Dep’t of Revenue, No. 2016CA1526 (Fla. Cir. Ct. July 6, 2016).

${ }^{5}$ See, e.g., Amy Hollyfield, Florida Joins Other States in Ending Tampon Tax, Tampa Bay Times (May 25, 2017), https://www.tampabay.com/florida-joins-other-states-in-ending-tampon-tax/2325147/ [https://perma.cc/HZ6A-BBVS].

${ }^{6}$ PERIOD EQUITY, http://www.taxfreeperiod.com [https://perma.cc/K9EX-FRZJ].

${ }^{7} I d$.

${ }^{8} I d$.

${ }^{9}$ Pregnancy Discrimination Act of 1978, Pub. L. No. 95-555, 92 Stat. 2076 (codified as amended at 42 U.S.C. $\S 2000 \mathrm{e}(\mathrm{k}))$.
} 
inability to work."10 The PDA itself was passed in response to two prior Supreme Court comparison-drawing cases in the pregnancy context: Geduldig v. Aiello ${ }^{11}$ (which arose under the Equal Protection Clause) and General Electric v. Gilbert ${ }^{12}$ (which arose under Title VII). In those cases, the Supreme Court held that treating pregnancy less favorably than other medical conditions did not necessarily amount to sex discrimination, because the relevant comparison was not between men and women, but rather between "pregnant women" and "nonpregnant persons."13 The PDA rejected that reasoning, shifting the comparative frame (at least in the Title VII context) from pregnant women versus nonpregnant persons to pregnant employees versus non-pregnant employees. But it retained the underlying comparative approach. To win pregnancy accommodation claims under the PDA, it is not enough for plaintiffs to show that their pregnancy-related needs were not accommodated; they must also show that analogous requests by equally-limited non-pregnant employees were granted. ${ }^{14}$

This piece explores the complexities of the comparative model as applied to sex discrimination claims that are connected to female biology. On the one hand, comparisons can be a useful and precise way to pinpoint discrimination. The notion that bandages and adult diapers are tax-exempt, while tampons and pads are not, brings the unfairness of the tampon tax into sharp relief: Why are those products for absorbing bodily fluids tax-free, when menstrual products are not? The same is true for a pregnant employee who can show that her request for a light-duty accommodation was denied while the identical light-duty request by another similarly-situated, non-pregnant employee was granted.

But the model also contains two traps. First, almost no comparison is perfect. There is often some potential for distinguishing and line-drawing, some way to argue that the comparison does not fully hold up. Second, the comparative model is itself inherently limiting. The biological processes of menstruation and pregnancy (along with menopause

\footnotetext{
${ }^{10} I d$.

11417 U.S. 484 (1974).

12429 U.S. 125 (1976).

${ }^{13}$ Geduldig, 417 U.S. at 496-97 n.20; Gilbert, 429 U.S. at 136-39.

${ }^{14}$ The Pregnant Workers Fairness Act (PWFA) would change this regime by creating a free-standing accommodation right for pregnant employees, giving them far greater protection. At the time this Article went to press, the PWFA had passed in the House of Representatives (on May 14, 2021) and was pending in the Senate.
} 
and breastfeeding, which this piece does not address) are closely intertwined with female sex and have no obvious analogues. Indeed, these processes impose specific challenges and needs that are not borne equally across the sexes. Yet the comparative model reductively suggests that if no products receive tax-exempt status, or if no employees receive accommodations for their inability to work, there is no sex discrimination issue at all. Although advocates cannot escape the current comparative framework within which they must work — and indeed should use it to their advantage when possible — we should all remain mindful of the framework's ultimate limitations.

The piece begins by analyzing Young v. United Parcel Service, Inc. ${ }^{15}$ the 2015 Supreme Court case that grappled with how to apply the PDA's comparison-based standard. I discuss how Young illustrates the complexities of comparison and unpack the compromise approach that emerged. I then consider the potential usefulness of the Young approach to the tampon tax cases, while acknowledging that they arise under the Equal Protection Clause rather than Title VII. I conclude with some broader reflections.

\section{Young and the "Most-Favored-Nation" Question}

Peggy Young was a part-time UPS driver who became pregnant after suffering several miscarriages ${ }^{16}$ Her doctor advised her not to lift more than twenty pounds during the first twenty weeks of her pregnancy, or more than ten pounds after that point. ${ }^{17}$ But her job required her to lift up to seventy pounds (and up to 150 pounds with assistance). ${ }^{18}$ UPS denied Young's request for a "light-duty" accommodation, instead telling her that she could not work while under a lifting restriction. ${ }^{19}$ Young therefore had to stay home without pay during most of her pregnancy, losing her salary and health insurance. ${ }^{20}$

Young's subsequent PDA lawsuit raised a statutory interpretation puzzle. The PDA, as noted above, states that "[w]omen affected by pregnancy, childbirth, or related medical conditions shall be treated the same for all employment-related purposes ... as other

\footnotetext{
15575 U.S. 206 (2015).

${ }^{16} I d$. at 211.

${ }^{17} \mathrm{Id}$.

${ }^{18} \mathrm{Id}$.

${ }^{19} \mathrm{Id}$.

${ }^{20} \mathrm{Id}$.
} 
persons not so affected but similar in their ability or inability to work." Here, UPS's policy was to grant accommodations to three categories of employees: (1) drivers who had become disabled on the job, (2) those who had lost their Department of Transportation (DOT) certifications, and (3) those who suffered from a disability covered by the Americans with Disabilities Act. ${ }^{21}$ UPS argued that it had not violated the PDA because it was not accommodating any employees similar to Young. ${ }^{22}$ Rather, UPS was accommodating only those employees who fell into the above three categories, and was treating Young "just as it had treated all 'other' relevant 'persons" outside of those categories, pregnant or not. ${ }^{23}$ Young, in turn, argued that once an employer was accommodating any subset of workers with disabling conditions, "pregnant workers who are similar in the ability to work [must] receive the same treatment even if still other nonpregnant workers do not receive accommodations. ${ }^{24}$

The Supreme Court characterized Young as asserting that pregnancy confers a “"most-favored-nation' status," summarizing her argument as follows:

As long as an employer provides one or two workers with an accommodation - say, those with particularly hazardous jobs, or those whose workplace presence is particularly needed, or those who have worked at the company for many years, or those who are over the age of 55-then it must provide similar accommodations to all pregnant workers (with comparable physical limitations), irrespective of the nature of their jobs, the employer's need to keep them working, their ages, or any other criteria. ${ }^{25}$

This argument proved too much, the Court concluded: "We doubt Congress intended to grant pregnant workers unconditional most-favored-nation status.."

\footnotetext{
${ }^{21} I d$.

${ }^{22} \mathrm{Id}$.

${ }^{23} \mathrm{Id}$.

${ }^{24} I d$. at 221.

${ }^{25} \mathrm{Id}$.

${ }^{26} I d$. at 222.
} 
On the other hand, the Court recognized that giving an employer free rein to create categories that excluded pregnancy threatened to undermine the very purpose of the PDA. ${ }^{27}$ After all, the PDA was passed to overturn Gilbert, which had held that employers did not violate Title VII by treating pregnancy worse than illnesses and accidents. ${ }^{28}$ UPS's argument would essentially reinstate that regime.

The Young Court thus adopted a compromise approach that tracked the three steps of the familiar McDonnell Douglas framework for analyzing employment discrimination claims ${ }^{29}$ First, a PDA plaintiff could establish a prima facie case of pregnancy discrimination by showing that she sought an accommodation, that no accommodation was provided, and that the employer did accommodate other employees "similar in their ability or inability to work." ${ }^{30}$ Second, the employer could then respond by articulating a "legitimate, nondiscriminatory" reason for denying the accommodation. ${ }^{31}$ The Court cautioned, however, that this reason could not simply be that "it is more expensive or less convenient to add pregnant women to the category" of accommodated employees. ${ }^{32}$ Finally, at step three, the plaintiff could reach a jury by "providing sufficient evidence that the employer's policies impose a significant burden on pregnant workers, and that the employer's 'legitimate, nondiscriminatory' reasons are not sufficiently strong to justify the burden." ${ }^{33}$ The Court further explained that one way a plaintiff could demonstrate that the policy imposes a significant burden on pregnant workers was by providing evidence that the employer's policy "accommodates a large percentage of nonpregnant workers while failing to accommodate a large percentage of pregnant

\footnotetext{
${ }^{27} I d$. at $226-27$.

${ }^{28} I d$. at 227.

${ }^{29}$ Id. at 228-29 (citing McDonnell Douglas Corp. v. Green, 411 U.S. 792 (1973)).

${ }^{30} I d$. at 229.

${ }^{31} I d$.

${ }^{32} \mathrm{Id}$.

${ }^{33} \mathrm{Id}$.
} 
workers." 34 The Court remanded the case for further consideration under this new standard. ${ }^{35}$

\section{Applying Young to the Tampon Tax Litigation}

What does Young tell us about the types of comparisons that might work best in the tampon tax litigation? In one sense, nothing. After all, Young arose under Title VII (as amended by the PDA), while the tampon tax cases arise under the Equal Protection Clause. And although the PDA explicitly overturned Gilbert's interpretation of Title VII, Geduldig's Equal Protection interpretation has never been explicitly reversed. Thus, a strong reading of Geduldig might say that it shows that even directly on-point comparisons are irrelevant to tampon tax claims. If treating pregnant employees less favorably than other employees does not amount to sex-based discrimination, as Geduldig suggested, why would treating menstrual products less favorably than other products be any more problematic? Indeed, even if a plaintiff could show that every single other personal care product is tax-free besides menstrual products, who cares? Just as Geduldig held that it did not violate Equal Protection to treat "pregnant women" worse than "nonpregnant persons," maybe it does not violate Equal Protection to tax menstrual products and not tax non-menstrual products.

But there are reasons to push back against that very aggressive reading. First, Geduldig's basic underpinnings have become legally anachronistic. The case was decided in 1974, before a majority of the Supreme Court held in Craig v. Boren ${ }^{36}$ that sex-based discrimination by the government should trigger intermediate scrutiny. (Gilbert, which was based on Geduldig, also preceded Craig, albeit by weeks. ${ }^{37}$ ) In recent years, the Supreme Court has moved even further away from the formalistic approach underlying Geduldig's odd distinction between "pregnant women" and "nonpregnant persons," becoming quicker to recognize the sex discrimination implications of how pregnancy gets

\footnotetext{
${ }^{34}$ Id. at $229-30$.

${ }^{35} I d$. at 232. Justice Alito concurred in the result, although he framed the relevant comparison differently. Id. at 235-41 (Alito, J., concurring in the judgment). Thus, six justices ultimately agreed that Young's comparative argument provided the basis of a viable PDA claim.

36429 U.S. 190 (1976).

${ }^{37}$ Gilbert was released on December 7, 1976; Craig came out on December 20, 1976.
} 
treated..$^{38}$ Moreover, Geduldig itself did not hold that all pregnancy-related classifications - let alone all other classifications related to female biology - could never be viewed as sex-based classifications. Rather, the Geduldig decision simply ruled that not "every legislative classification concerning pregnancy is a sex-based classification." Thus, it left the door somewhat ajar for how other legislative classifications concerning pregnancy might be treated.

In some ways, classifications concerning menstruation present an even stronger case for being viewed as a form of sex discrimination. Geduldig distinguished between "pregnant women" and "nonpregnant persons," and—without endorsing Geduldig's reasoning - it is at least true that most women spend the vast majority of their lives as "nonpregnant persons." Menstruation, by contrast, is a regular occurrence throughout most women's lives for an average of four decades. Of course, menstruation is not a daily occurrence, but it is regular enough that those who menstruate must consistently plan ahead to ensure they have procured the products they need. The tampon tax is thus relevant during a significant portion of the lifetimes of those who menstruate.

Assuming, then, that Geduldig does not entirely foreclose tampon tax claims, we still must sort through which comparisons work and which do not. If a state exempts bandages and gauze pads but not menstrual products from taxation, does that create a stronger constitutional case than a state that exempts only prescription drugs? Where do exemptions for non-necessities, like tattoos, fit in? Here is where Young may be useful. Its approach — while not technically binding here - is adaptable to this context, at least for courts who are open to doing so.

As an initial matter, it must be acknowledged that Young rejected a "most-favorednation" approach — which makes it a hard sell here, too. That a state gives a tax exemption to one product is probably not enough to mean that it must exempt menstrual products as well. Of course, there are strong policy reasons for exempting menstrual products from taxation, regardless of which other exemptions exist. But the legal argument is tougher.

When a state is providing tax exemptions to a sizable number of other products, though, the case becomes stronger - and Young provides a road map. Borrowing from Young, the first step would be for a plaintiff to show that menstrual hygiene products are

\footnotetext{
${ }^{38}$ See, e.g., Neil S. Siegel \& Reva B. Siegel, Pregnancy and Sex Role Stereotyping: From Struck to Carhart, 70 Оніо Sт. L. J. 1095, 1106 (2009); see supra text accompanying note 13.

${ }^{39}$ Geduldig v. Aiello, 417 U.S. 484, 496 n.20 (1974) (emphasis added).
} 
being taxed by the state while other "similar" products are not. Young did not prescribe exactly which employees count as "similar," and plaintiffs should likewise have some room here. For example, other products might be similar to menstrual products because they have a similar function (e.g., other blood-absorbent products), play a similar role (e.g., other "necessary" personal care products like anti-perspirant), or are used in connection with similar areas of the body (e.g., condoms or hemorrhoid remedies). The arguments will likely vary from state to state. A state would then need to respond at step two by articulating a "legitimate, nondiscriminatory" reason for exempting other similar products and not menstrual hygiene products. And, as Young puts it, that reason could not simply be that "it is more expensive or less convenient to add [menstrual hygiene products] to the [tax-exempt] category."

Finally, at step three, the plaintiff could respond by "providing sufficient evidence that the [state's] policies impose a significant burden," and that the [state's] "'legitimate, nondiscriminatory' reasons are not sufficiently strong to justify the burden." 41 Moreover, per Young, the plaintiff could prove that there was a significant burden by showing that the [state's] policy ended up "[exempting] a large percentage of [similar products] while failing to [exempt menstrual products]."

Young's reasoning thus indicates the wisdom of advocates' comparison-based strategy for challenging the tampon tax. Moreover, Young provides a road map for courts to analyze such claims. While Young's approach certainly is not binding, the Supreme Court's adoption of it for pregnancy accommodation claims counsels toward adapting it to other sex discrimination claims that are similarly intertwined with female biology.

\section{CONCLUSION}

In advocating for Young's migration to the tampon tax context, I note that Young also comes with costs. Young not only rejects the "most-favored-nation" idea, but also suggests that finding a similar analogue is the only way to prevail. This notion that similar comparators are required fits uneasily with claims that stem from biological differences. The processes connected with the female reproductive cycle-menstruation, menopause, pregnancy, and breastfeeding - do not have perfect comparators. Young at least suggests that "similar," rather than perfect, comparators are good enough, which is

\footnotetext{
${ }^{40}$ Young v. United Parcel Serv., Inc., 575 U.S. 206, 229 (2015).

${ }^{41} I d$.

${ }^{42} I d$.
} 
encouraging. Even finding a similar comparator, however, can sometimes be impossible. That is troubling, since regardless of whether there is a similar comparator, these biological processes are imposing real costs and needs - unequally borne across the sexes - that require consideration and accommodation in order to achieve true social equality. Young is thus a helpful starting point, but it also indicates the need for a continued multi-pronged menstrual equity strategy that includes public policy advocacy as well as litigation. 